\title{
Mainstream Media Politics in the Presidential Election of the Republic of Indonesia 2019
}

\author{
Anang Sujoko \\ Political Communication \& Media Studies, Universitas Brawijaya-Indonesia \\ Email: anangsujoko@ub.ac.id
}

\begin{abstract}
Mass media has the power to build a discourse on public discussion. This strength should be used in carrying out its function as a watchdog in democratic practice. The mass media must break away in a position as part of the executive or legislative because he himself is the fourth force in the pillar of democracy. In the 2019 Indonesian Presidential Election (Pilpres) the mass media showed practices that weakened this position with the presence of affiliated media owners or even became part of the political parties supporting one of the candidate pairs in the 2019 Presidential Election. This paper is critical thinking about how politics mainstream mass media in Indonesia in polarizing support to candidate pairs. The data are collected through observation of media content and in-depth interviews with informants from media workers and informants who have competence in the field of mass media. The results of the study show that mainstream mass media tends to still be positioned as the main source of information in the five-year democracy event. The preaching of mainstream mass media still shows partiality to certain candidate pairs by not expressing criticism and vice versa often showing criticism on other candidate pairs. The mass media that have affiliations to political parties tend to show partiality to the authorities and ignore the critical role in overseeing government practices. The oligarchy of the media industry in Indonesia has not shown the role of overseeing the social and political environment.
\end{abstract}

Keywords: Media Politicization, Media Watchdog, Media Alignments, Media Oligarchy, Democracy.

\section{A. INTRODUCTION}

The 2014 presidential election, the events of the Peace Bela Islam 212 in 2016, the DKI Jakarta Governor Election 2017, Reunion 212 in 2018 and the 2019 Presidential Election were the parameters that many media observers criticized to find out the extent to which the media took the role of watchdog. The 2014 presidential election which appointed two candidate pairs became the issue of the cause of polarization of media support and division. The community has easily been able to recognize how the media are aligned with one of the candidate pairs. The media can no longer hide its alignments through reporting. Or in other words, the way the media reports or doesn't even report an event can easily show the media's partiality to one of the candidate pairs. In addition, the openness of information and the incessant self-promotion of several elite political party owners of media in their media actually bear fruit in the critical thinking of the public. In the perspective of positivism, McCombs, et al. (2014), show that mass media has the power to influence the formation of the public agenda, even with the development 
of social media that power is growing. With the growth of users of social media in Indonesia, the formation of public issues is getting stronger by originating from the news of mainstream mass media and then continuing through discussions on social media so that the issues develop in debates or even voluntarily disseminate in social media groups (Meraz, 2013; Vargo et al., 2014). On the other hand, Sujoko \& Larasati (2017) research, Messner \& Garrison (2011); Wallsten (2007) reveal that a hot issue on social media can become an interesting one in mainstream mass media.

If we look at how mainstream mass media currently also have online media and social media accounts, then what really becomes the power of the media cannot be avoided. This means that regardless of one's motivation in seeking information, the power of the media in influencing the public to think about certain issues and how to think about the issue is no longer just a discourse. The next question is whether mainstream mass media or even online mass media can carry out their role as watchdog if the owners are administrators of political parties who are directly involved in the process of supporting one of the candidates in the 2019 Presidential Election contest.

\section{B. METHOD}

This descriptive qualitative study uses data collection techniques in the form of imaginary interviews and observations of the contents of the mass media that clearly have affiliation support to one of the candidates in the 2019 Presidential Election. Informants are media workers or former media workers in mainstream mass media groups.

\section{RESULT AND DISCUSSION}

\section{Media Owner and Elites of Political Parties}

There are three mass media industry groups in Indonesia whose owners are linked to political parties namely the Media Group, MNC Group, and Bakrie Group. Media Group consisting of Media Indonesia, MetroTV, News One, and several prints and online media owned by Surya Paloh. He is a figure known to the public as part of the standing and operation of Media Indonesia and MetroTV. Besides being known as MetroTV, Surya Paloh is also very attached to the Nasdem Party. Even in his political journey, he did not hesitate to use his media in supporting political travel both personally and in political parties. He has used this since losing the election as Golkar's general chairman (Tapsell, 2017).

MNC Group consisting of MNC TV, RCTI, GTV, INews, and okezone.com is the largest media group controlled by Hary Tanoe. At the beginning of his political career, he joined Surya Paloh in Nasdem, but finally, Hary Tanoe decided to establish his own political party called Perindo. The media-affiliated media can also be read to tend to promote Hary Tanoe and Perindo. A similar thing also happened in the Bakrie Group owned by Aburizal Bakrie. Aburizal Bakrie is a senior Golkar Party member and has competed 
with Surya Paloh in taking the chair of the general chair. The ownership of the media by the elite of the Golkar political party also clearly shows the use of the media to favor the owner.

A study conducted by the Media Care Society increasingly confirms the exploitation of the media for the political interests of media owners (Tempo, 2019). The scientific study revealed how MetroTV and Media Indonesia clearly treated the interests of Surya Paloh and Nasdem in particular. The same thing was also explained by Amir Efendi Siregar of the Regulatory Monitoring and Media Regulator (PR2M) who said that excessive exploitation of the use of mass media was in the interests of elite political parties (Tempo, 2019).

The elite ownership of political parties in the mass media in a critical political economy perspective is indeed not only talking about how the media can make as much money as possible but how the media is also able to realize the interests of the political owner's political ideology (Mosco, Vincent, 2019). The interests of the capitalist media place media no longer as part of a press system with noble functions to carry out social oversight and means of control government, but the media is a money machine and individual popularity.

The practice of dominating the use of media for the benefit of owners in Indonesia is a form of castration of public rights to the media. Media as an extension of the human senses (McLuhan, 1964), which of course for noble interests, should always prioritize public rights to obtain information, entertainment, and health education. While with these capabilities, the media can no longer only influence the discourse in the public sphere, but the media can also influence how the public thinks about an issue that is raised by Commb (2014). Therefore a public disaster if the media has been co-opted for capitalist interests.

\section{The Collapse of the Power of the Pillar of Democracy}

The Peace Action to Defend Islam 411 and the Islamic Defensive Action "212" in 2016 triggered by popular discontent over the indecisiveness of law enforcement officials and the authorities, were considered Marlyna Lim (2017) as a peaceful demonstration by raising statements such as "love of Islam" and "Love NKRI. Lim (2017) does not agree if the peaceful action is matched by similar movements carried out by Ahok supporters as a fact that can be placed as a dichotomy between democracy vs. anti-democracy, diversity vs. anti-diversity and tolerance vs. anti-tolerance. However, some mainstream media such as MetroTV, BBC, iNews and MetroTV framing tend to be negative towards this movement (Zaelani \& Santana, 2017; Pradipta, et.al, 2018).

If you look at the background of this series of movements and the originators of the idea of action, this mass mobilization is a form of protest to the government which is 
considered not serious in dealing with events that allegedly involved the abuse of religious values. The action involving the largest masses in the history of the mass movement in Indonesia became very extraordinary because the participants were very orderly and very concerned about the environment. But it is unfortunate that the mainstream mass media actually judges from the side that should be a defender of the movement in controlling the authorities very peaceful even very orderly. From the way, the media reported this shows that the mass media has shifted as defenders of the authorities.

The practice of media exploitation by media owners such as Surya Paloh, Aburizal Bakrie, and Hary Tanoe is a form of denial of the role of the press which should defend the public interest and become independent controlling force. Some facts such as not being appointed a major event demonstration of hundreds of members of the All Indonesia Executive Board in front of the Indonesian Presidential Palace, demonstrations of honorary teachers throughout Indonesia in front of the Palace, a grand reunion event 212 and stunting a series of Islamic defense actions by media incorporated in Media Group, CT The Group, MNC Group, and Kompas are a black record of the history of the press in Indonesia. Rocky Gerung and Effendi Gazali call it historical embezzlement (Nigara, 2019). Arief (2018a) even responded to the low coverage of mainstream mass media on extraordinary journalistic events in the actions of the Islamic Peace Defense 212 and the 212 Great Reunion as a form of mass press suicide in Indonesia. The news values in the study and journalistic practices that have been the guideline of media workers and press activists seem to have absolutely no power at all to be called news. Co-optation, framing, and blackout on major events by mainstream mass media simply because it will benefit the opposing party in the 2019 Presidential Election contestation is a picture of the press worshiping the ruler (Arief, 2018b).

The mainstream media practices of MetroTV, Detik.com, Kompas who are always looking for negative gaps from Prabowo's camp and affiliated groups as supporters, but on the other hand always bombard the contents of the media with positive events involving incumbents and supporters is a murder sadistic character of the press and journalistic values.

\section{CONCLUSION}

Media ownership by the elite of political parties has obscured the role of the media, which should be for the public interest for the primacy of their owners. Whereas the role of the media which is supposed to be the fourth power of democratic practice has collapsed and is fully in control of the interests of the capitalist political economy. The collapse of the fourth pillar of democracy by the media makes the ruler not have the power

of voluntary control. Furthermore, the loss of the role of watchdog by the media is not because of the authoritarian rule of the authorities, but because media owners voluntarily make the media a cult of power. 
This study has not examined how the Media Group allocates time for the reporting of the Islamic Defensive Axis 212 and the Islamic Defensive Action 411 so that in the future there needs to be a special study to uncover how the Media Group's impartiality in actions considered anti-Jokowi.

\section{REFERENCES}

1. Arief, H. (2018a). Bunuh Diri Jurnalisme. Accessed July 8, 2019, at https://kumparan.com/hersubeno-arief/bunuh-diri-jurnalisme-harian-kompas1543994975364887625.

2. Arief, H. (2018b). Skenario Besar di Balik "OTT". Accessed July 8, 2019, at https://kumparan.com/hersubeno-arief/gagalnya-operasi-politik-dan-media-diakhir-tahun-1546058362495117772.

3. Lim, M. (2017). Freedom to Hate: Social Media, Algorithmic Enclaves, and the Rise of Tribal Nationalism in Indonesia. Critical Asian Studies, 49(3), 411-427.

4. McCombs, M. E., Shaw, D. L., \& Weaver, D. H. (2014). New Directions in AgendaSetting Theory and Research. Mass Communication and Society, 17(6), 781-802.

5. Mosco, V. (2009). The Political Economy of Communication. London: Sage Publications.

6. Nigara, M. (2019). Mempertanyakan Netralitas Dewan Pers. accessed July 8, 2019, at https://www.kanigoro.com/artikel/mempertanyakan-netralitas-dewan-pers/.

7. Pradipta, A. L., Hidayah, N. W. N., Haya, A. N. A., Ervani, C., \& Kristanto, D. (2018). Analisis Bingkai Pemberitaan Aksi Bela Islam 2 Desember 2016 (Aksi 212) di Media Massa BBC (Indonesia) \& Republika. Informasi, 48(1), 109-124.

8. Tempo. (2019). 7 Media ini Dituding Berpihak dan Tendensius. Accessed July 8, 2019, at https://nasional.tempo.co/read/565574/7-media-ini-dituding-berpihak-dan-tendensius.

9. Zaelani, M., \& Santana, S. K. (2017). Konstruksi Berita Aksi Damai 212; Analisis Teks Berita melalui Framing Robert N. Entman terhadap Aksi Damai 212 pada INews TV dan Metro TV. Prosiding Karya Jurnalistik, 3(2), 180-185. 